to problems in wool chemistry. With his colleagues he has developed methods for the analysis of amino-acids and amino-acid derivatives, determined the amino-acid composition of wool and of proteins isolated from wool, and examined the distribution of sulphur in wool. The last-mentioned of theso topics was supported by a grant from the United States Department of Agriculture, and led to the discovery of two new sulphur-containing amino-acids. Dr. Robson will retain responsibility for the direction of a new research project on which he and his colleagues at the Wool Industries Research Association are at present engaged, and which is also sponsored by the United States Department of Agriculture.

\section{Medical Biochemistry in the University of Manchester:} Prof. D. S. Jackson

DR. D. S. JACkson has been appointed to be the first holder of the chair of medical biochemistry in the University of Manchester. Dr. Jackson, now aged forty-threo, was educated at Farnworth Grammar School, and served from 1940 until 1946 in the Royal Air Force before entering the University of Manchester. He graduated B.Sc., with honours in chemistry, in 1949, and Ph.D. in 1954. He has been interested throughout his career in the medical applications of chemistry and biochemistry. As a rescarch assistant in the Rheumatism Research Centre, he became concerned with the nature of collagen and reticulin, and with the response of tissues to the irritant carrageenin. In 1954-55 he was Visiting Fellow at the National Institute for Medical Research, with Prof. A. Neuberger. From 1957 until 1959 he was a research associate in biochemistry at the Harvard Medical School, and in 1959 he went to the medical school of the University of Oregon as assistant, and later associate professor. In 1962 he was appointed professor of biochemistry, and also head of the Surgical Research Laboratories in Oregon. Dr. Jackson's published work has been concorned with the proteins of connective tissue, and more recently with wound healing and tissue reaction to foreign materials and to tumours. $\mathrm{He}$ has also developed new approaches in the teaching of biochemistry to medical and biological students. His return to Britain, and to his own University, is welcome.

\section{Experimental Psychology in the University of Sussex :}

\section{Prof. N. S. Sutherland}

THE progress of the behavioural sciences in Britain will be notably furthered by the establishment of a chair of experimental psychology at the University of Sussex and the appointment of Dr. N. S. Sutherland to it. A recruit to psychology from 'Greats', Dr. Sutherland followed this with the Oxford Final Honour School of Psychology, Philosophy and Physiology, and was afterwards elected to a fellowship by examination at Magdalen College. Encouraged by Prof. J. Z. Young in his interest in the visual discrimination mechanisms in Octopus, he and his colleagues have, in the past ten years, made a massive and penetrating investigation of stimulus-analysing mechanisms in both vertebrates and invertebrates. Dr. Sutherland is also well known for his contributions to human psychology, especially in the fiold of learning and memory. Appointed University lecturer in experimental psychology at Oxford in 1960, he was elected to an official fellowship at Merton College in 1962. He has played a large part in the development of the subject at Oxford, through a period of rapid and difficult evolution. His many friends and colleagues, not only in Britain, but also in the United States, will look forward with great interest to the development of the new department at Sussex.

1964 Guggenheim International Astronautics Award : Prof. W. O. Fenn

ThE Daniel and Florence Guggenheim International Astronautics Award for 1964 has been conferred on Prof. Wallace O. Fenn, of the Department of Physiology in the
University of Rochoster School of Medicine and Dentistry. Dr. Fenn is well known for his work in maxiy of the biological sciences, including respiratory problems, the mechanics of running and bodily movements, heat production of muscle, potassium and other electrolytes in muscle, and oxygen requirements of stimulated nerves. Since 1959 he has been secretary-general of the International Union of Physiological Sciences. He has been an active member on numerous committees of leading American scientific institutions, such as the National Research Council, the Research and Development Board, the National Science Foundation, and he has served at times as chairman of the Physiological Training Grant Committee and of the Physiology Study Section of the National Institutes of Health. His achievements have been widely recognized and earlier this year he received the Antonio Foltrinelli Prize for experimental medicine. The presentation of the Guggenheim International Astronautics Award will be made during the fifteenth Congress of the International Astronautical Federation, which will be held in Warsaw during September 7-12. The Award, which carries a prize of 1,000 dollars, has been made annually since 1961 , but this is the first time that it has been awarded to a scientist working in the field of physiological research.

\section{British Aviation Research}

REPLYING to a question in the House of Commons on July 8, the Minister of Aviation, Mr. J. A.mery, said that the Ministry's research and development establishments, in co-operation with industry, were devoting considerable effort to problems of approach and landing guidance, long-range navigation, communications, ground data handling and processing systems, the application of automation to future air traffic control systems and the use of micro-electronics techniques for civil aviation equipment. $\mathrm{His}$ department would also finance most of the British share in the development of the Concord supersonic transport aircraft, which entails the development of advanced electronic systems. Links with industry had recently been strengthened and they were very much aware of the need for the fullest dissemination of information.

\section{Research and Development for Power}

IN a written answer in the House of Commons on July 29, the Parliamentary Secretary to the Ministry of Power, Mr. J. Peyton, stated that the combined expenditure on research and development by the nationalized coal, gas and electricity industries had increased from about $£ 6$ million in 1958-59 to about $£ 12$ million in 1963-64. In conjunction with manufacturers, the National Coal Board had made significant progress in developing equipment for the widespread mechanization of coal winning, and more recently for applying remote control techniques to mining. Pioneer research by the Gas Council had led to the development of new processes which were bringing about a technological revolution in the production of gas. The Central Electricity Generating Board had expanded its central research laboratories and built new laboratories for nuclear and engineering research.

\section{Solway Firth Barrage}

IN reply to questions in the House of Commons on July 22, Mr. G. Campbell, Under-Secretary of State for Scotland, said that the proposal for a barrage in the Solway Firth was being examined jointly by the Scottish Development Group in its investigation of South-west Scotland and by the North-west England Regional Development Group. The Secretary of State for Scotland was aware of the interest of the University of Strathclyde in this problem and he was sure that it was being examined urgently. The Scottish Office was considering all representations which had been made on this subject, including the memoranda submitted by Dr. R. Drew. 


\section{The Price of Education}

IN reply to questions in the House of Lords on July 7 , the Earl of Bessborough said that, for the present year, capital and recurrent Exchequer grants to the universities were estimated at $£ 133$ million compared with $£ 58$ million in 1959 , when there were 24 university institutions, compared with the present 33 . Over the same period the number of full-timo students had risen from 104,000 to 125,000 , and of full-time teachers from 12,000 to 15,000 . Those figures did not include the colleges of advanced technology and certain Scottish institutions which were achieving university status. The proportion of women students had rison from about 24 to 27 per cent. In the House of Commons on July 6, in reply to it question, the Secretary of State for Education and Science, Mr. Q. Hogg, stated that the total educational expendituro of public authorities in Great Britain, including expenditure on school meals and milk, rose from $£ 479$ million in 1952 53 to $£ 1,277$ million in $1962-63$, or from 3.4 per cont to $5 \cdot 1$ per cent of the gross national product. In terms of constant prices the increase was estimated at about 75 per cent over the period, about half being attributable to an increase in the number of pupils and students.

\section{British Aid to Development}

IN a written answer in the House of Commons on July 30 , the Chief Secretary to the Treasury, Mr. J. BoydCarpenter, stated that the Government had announced to the United Nations Conference on Trade and Development Britain's intention of increasing her contribution to the Unitod Nations Special Fund and to the Expanded Programmo of Technical Assistance, to contribute to the African Development Bunk, and to examino sympathetically the possibility of assisting other regional development banks. Britain was contributing in one form or another ₹7.1 million to the resources of the Inter-American Dovolopment Bank and her annual contribution to the International Development Association had been in creased. At the recent meeting of Commonwealth Prime Ministers proposals were announced for a scheme of Commonwealth Dovelopment Projects, increased capital aid for higher education and an expansion of training facilities for senior administrators from developing countries in the Commonwealth. On this the Prime Minister had said in the House of Commons on July 23 that the proposals for a Commonwealth Foundation to encourage professional exchanges had been romittod to Commonwealth officials for study. He stated that he would not exclude the idea of a Foundation extending its activities to include training and exchanges of technical personnel. Much would depend on the funds available and the Foundation was dovised essentially to promote professional links. Mr. Boyd-Carpenter continued that Britain would, at the third Commonwealth Education Conference at Ottawa in August, make proposals to expand and improve the Commonwealth Educational Co-operation Scheme. Recent specific bilateral commit. ments included provision of $\$ 52$ million of economic aid for Kenya over the next three years, E5l million for Malta ovor the next ten yoars subject to satisfactory con. tinuation of the defence arrangements, and increased aid for the Sudan. Expenditure on non-military aid in 1963-64 was $£ 175$ million and on military aid $£ 30$ million.

\section{Japanese Aid}

IN the past decade Japan's gross national product has risen by about 10 per cent per annum, and in the nonCommunist world only the United States, West Germany, the United Kingdom and France have a higher gross nutional product. With a programmo of aid to developing countries of $£ 60$ million a year, she is also the fifth largest of the non-Cornmunist donors. but a survey, Japanese Aid, by $\mathrm{J}$. White, issued by the Overseas Development Institute, concludes that most of this is designed to help
Japan's economic expansion rather than doveloping countrios (Pp. 78. London: Overseas Developmont Institute, Ltd., 1964. 6s.). The survey reviews first the motives and objectives of Japanese aid. and then the mechanisms used and the flow of resources. It is pointed out that Japanese aid should not be judged by Westorn standards and attention is directed to some defects in tho present systom. This appears to be based on principles of selection which have little to do with tho requirements of the recipients and neither enhances the programmes of other donors nor is enhanced by them. The booklet should contributo to a better understanding betwe $x$ Japan and the West, and $\mathrm{Mr}$. Whito suggests that in practice Japan should be encouraged to participate to a groater extont in programmes which require dotailed consultation and co-operation with other donors, and to administer a higher proportion of its aid on the basis of Government-to-Government agroements.

\section{Infant and Neo-natal Mortality}

THE Office of Health Economics set up in 1962 by the Association of the British Pharmaceutical Industry has recently published a pamphlet entitled Infants at Risk, which gives an account of infant and neo-natal mortality, and makes a number of historical comparisons ( $\mathrm{Pp} .36$. London: Office of Health Economics, 1964. 2s.). As is well known, infant mortality in Britain has been declining since the beginning of the twentieth contury, but the rate of decline has slackened since the mid-nineteen-fifties. Howover, the social pattern of infant mortality has persisted almost unchanged since Edwardiun days: in other words, different social groups in the community have benefited uniformly. The recent slowing down in the rate of decline means that Britain now lags behind countries such as Swedon, and a reduction of the British infant mortality rate to the Swedish level would mean a reduc. tion of 4,000 infant deaths per annum. The report suggests that a more extensive use of ante-natal services on the part of expectant mothers might be instrumental in highlighting their present inadequacies and help in roducing the wastuge immediately after birth.

\section{Scientific Research in British Universities and Colleges, 1963-64}

THE 1964 odition of Scientific Research in British Universities and Colleges contains brief notes on scientific research in progress in British universities and colleges (including colleges of technology), and describes the nature of the projects in sufficicnt detail to indicate the scope of the research carried out by the various science departments and individual tearns of investigators (Pp. $\mathrm{xxv}+727$. London: H.M.S.()., 1964. 35s. not). The social sciences and industrial administration are not included except where work in these fields normally occurs within the science faculty or technology department. Universities and colleges are listed alphabetically and under each are entered departments, and in many cases sub-departments and affiliated institutions, etc. The staff of each department are listed along with their qualifications and present fields of research. Indication is made where members of staff are affiliates of the Agricultural Research Council or Medical Research Council. The three indexes, "List of Subject Headings", "Name Index" and "Subject Index", make this publication one of the most useful guides to scientific research in British universities and colloges. The publication is issued jointly by the Department of Scientific and Industrial Research and the British Council.

\section{Soviet Technical Literature}

Tematicheskiy Plan-1964 is a complete listing in English by subject-matter of all books scheduled for publication by the Soviot Academy of Sciences in 1964 (Pp. iv +132 . London: Scientific Information Consultants, Ltd., 1964. 70s.; 10 dollars). Each entry gives 